\title{
The Black Seasons (Czarne sezony)
}

Author: Michał Głowiński

First Published: 1998

Translations: Czech (Černé sezóny, 2002); English (The Black Seasons, 2005); German (Schwarze Jahreszeiten: meine Kindheit im besetzten Polen, 2018).

About the Author: Michał Głowiński (1934) was born in Warsaw into a Jewish family which was deported to the ghetto at the beginning of the war. He was one of the Jewish children saved by Irena Sendlerowa's team in the children's part of Żegota which was the Polish Council to Aid Jews. After World War II, Głowiński became a distinguished literary researcher and critic, on top of being a professor at both the University of Warsaw and of Cracow. He is well known for his analysis of Communist newspeak (Totalitarian Speech [Nowomowa po polsku], 1990) as well as the various ways of reception of literary works (reader-response theory) (Styles of Reception, 1971), in addition to his student and academic handbooks of Polish literature. He was also engaged in the Solidarity movement during the Communist regime.

Further Important Publications: Kręgi obcości. Opowieść autobiograficzna (2010, Circles of Foreignness: Autobiographical Story); Realia, dyskursy, portrety: studia i szkice (2011, Realities, Discourses, Portraits: Studies and Essays); Carska filiżanka: szesnaście opowieści (2016, Tsar’s Cup: Sixteen Stories).

\section{Content and Interpretation}

The action begins with the outbreak of the war, just a moment before the deportation to the ghetto, which excites the little boy and stimulates his imagination - but quickly gives way to his understanding and disappointment. The first part of the book consists of his memories from the ghetto, filtered through the eyes of a child, along with numerous gaps, and blank spots of memory, which the author hesitates to fulfil with factual information.

The second part of the book, which describes the time just before and after escaping from the ghetto, is a story of hiding and fear, divided into fragments, episodes and detached images that have been preserved in memory. Many of them have a metaphorical dimension, which gave literary scholars the incentive to reflect on the specific form of Głowiński's narration, which is filtered through literature, art and psychology, and which becomes not so much an act of remembrance rather than of self-therapy and psychoanalytical vivisection. One of the strongest memories that the author describes is hiding in the cellar together with other residents of the tenement house at the beginning of the liquidation of the ghetto. Głowiński concludes "that sojourn in the cellar has remained with me to this day, it did not come to an end with the opening

Ә Open Access. () 2021 Agata Firlej, published by De Gruyter. (c) BY-NC-ND This work is licensed under a Creative Commons Attribution-NonCommercial-NoDerivatives 4.0 License. https://doi.org/10.1515/9783110671056-007 
of the doors" (Głowiński, 2005, p. 13). The author remembers that there was a terrible crowd in the basement, it was dark, no one could make any sound. At some moment, however, the silence was broken by a small, several-month-old child who began to cry. His mother tried to silence him, but nothing worked, even tranquilizers. Each of the people hiding began to fear for their own life and this fear became almost tangible - just like the atmosphere of growing hostility towards the crying baby; even for the narrator, who was also a child himself, it became clear that the toddler would have to be silenced: there was a suggestion that it should be strangled. Such a psychological experience leaves its mark forever - leaving an inner doubt in human altruism and solidarity during the moment of threat.

In another place Głowiński considers a certain "leap" in his literary formation: after the war, when his non-Jewish colleagues recalled their favourite childhood readings, fairy tales or adventure novels, he did not have any such memories. After surviving the war it was no longer possible to make up for these reading deficiencies: this experience had deprived him of this kind of naivety, which is necessary to be able to delight over adventure novels. Isolation and a sense of foreignness, which became the subject of reflection in another autobiographical book by Głowiński (Circles of Foreignness), are also drawn here in a subtle way. Through the use of specific key words and metaphors, rhetorical and narrative structures, The Black Seasons is read as a modern, hybrid literary form, a fresh way of writing about the Shoah. Such literary devices are effective ways to describe trauma. Głowiński has many complications connected with determining the duration of events and with time itself. In many places the narrator helplessly gives up any attempt to organise the chronology, he does not speculate about how long individual events took place, e.g. the hiding in the cellar. The solution is to allow one's subjective sense of time to take precedence over the objective one; the narrator repeatedly warns the reader on the pages of his book that he does not control the chronology of the scourge on the Aryan side. The length of the Holocaust is undoubtedly the longest lasting time, as it stays forever in the memory of every person "singed": this last term refers to the title of Irit Amiel's collection of stories; after reading it, Michał Głowiński postulated that the term "singed", defining the survivors and the second generation, should permanently be entered into the dictionary. One of the most outstanding and most frequently quoted examples taken out of The Black Seasons is the situation of the blackmailer's arrival for their payment: when the main character's aunt runs out of the house to get the money, the remaining family is experiencing the agony of waiting for what seems to last forever. They do not know if the aunt will come back before the man changes his mind and gives them up to the Germans. Blackmailer, meanwhile, decides to play chess with the narrator (then still a little boy, aware, however, that he is actually playing for his life): this situation is almost a quote from the famous film The Seventh Seal by Ingmar Bergman, in which the main character plays chess with Death itself.

Along with the factual running of time of the Holocaust and the subjective time of the narrator, another kind of time is in play; natural or biological time. "It was hot, the 
sun was shining. The season of great dying reached its fullness at the height of summer”, Głowiński wrote (p. 15), and further on the sun: "it was cruel and inhuman, like everything else behind the ghetto walls, it intensified suffering, it brought no hope, but rather scorched even more those condemned to death" (p. 16). Therefore, the whole of Nature participates in the cruelty of events arranged by people; this way of writing also belongs to the established repertoire of literary topics, and such a distinguished literary scholar as Michał Głowiński is perfectly familiar with it. The chaotic stream of memories, flashes of memory, is organised by literary consciousness; it is built on the basis of a kind of questionnaire (time, space, language, episodes, characters, metaphors). "In my memories, the color of the ghetto is the color of the paper that covered the corpses lying on the street before they were taken away" (p. 7), recalls the writer. He adds: "Precisely a color without color - neither white nor ash, nor even gray - defines the colorscape of the ghetto and imparts its tone" (p. 7). What immediately refers to the latter, postwar memory, associated with the artistic sphere: once he noticed this specific color-without-color again in Andrzej Wajda's black and white film about Janusz Korczak (1990). Apart from the ghetto, Umschlagplatz and Treblinka, also the cellars left a strong mark on Głowiński’s memory. The writer particularly remembered and described these places which became the spaces of his psyche. For years he struggled unsuccessfully and without hope with his own inner "cellars"; fears and claustrophobia. The cellar is for him a space filled mainly with anxiety. A young Głowiński also met with similar confinement during the train transport from the ghetto in Pruszków to the Warsaw Ghetto. There, too, huge amounts of people were squeezed together in a small, dark, stuffy space. All these closed spaces create a claustrophobic sphere, separated from the rest of the world in Głowiński's book, and at the same time they are ambivalent: both a prison and a hope for safety. This ambivalence is yet another emblematic moment in Głowinski's work and at the same time - like all the components of his work described above -it is the sign of a specific, separate style of Shoah literature, which can be found not only in his books. $\rightarrow$ The Jewish War; $\rightarrow$ The God's Horse.

\section{Main Topics and Problems}

Michał Głowiński revealed his Jewish origins and traumatic war experiences after many years, on the threshold of his old age and he is not isolated in his late debut, although - as Henryk Grynberg described it with irony - he broke the record with his fifty years of silence. The same experience of late debut share with him Miriam Akavia, Ida Fink, Wilhelm Dichter, Irit Amiel, Krystyna Żywulska, Roma Ligocka and many others. It is characteristic that most of them decided to write their memories in the decade of the nineties. Henryk Grynberg's initial reaction to the book was unfavourable: the writer accused Głowiński of being naive, and of repeating clichés. He also questioned Głowiński's decision to resign from filling in his blank spots of memory with factual material. The way in which Grynberg expressed criticism was also characteristic - he used terms derived from the Nazi war language: "the surprise was the debut of 
Michał Głowiński, a literary expert who, after fifty years on Aryan papers, admitted his Jewish past [...]”. Strongly defined terms ("Aryan papers", "he admitted”) may themselves be a psychological material for considering the durability of war syndromes, which Henryk Grynberg probably himself realised as he finally softened the evaluation of Głowiński's book and the phenomenon of late debuts; as he wrote: "the trauma of the Holocaust does not give way under the influence of time. That explains the late prose debuts of children of the Holocaust in the nineties" (Grynberg, 2011, p. 793). The main problem, then, is how the reader should treat Głowiński's text, as Bartłomiej Krupa remarks: "it is up to the reader to choose the criteria for assessing The Black Seasons. The criticism expressed by Grynberg builds the opposition - which can also be deduced from various statements and declarations made by Głowiński and which are also explicitly present on the pages of The Black Seasons - the opposition between the document and literature”. (Krupa, 2013, p. 295)

Ryszard Matuszewski counts The Black Seasons among the group of works giving "the highest artistic testimony of the Holocaust" and placed this book next to the $\rightarrow$ Medallions of Zofia Nałkowska, stories by Adolf Rudnicki ( $\rightarrow$ The Escape from Yasnaya Polyana), $\rightarrow$ The Jewish War of Henryk Grynberg, $\rightarrow$ Bread for the Departed by Bogdan Wojdowski and the output of Hanna Krall. The modality of words (like possible worlds, coincidence, probability, fiction) is a specific feature of Głowiński's output, according to Ubertowska, where upon the common understanding of the word, the theoretical literary (narratological) grid is imposed. The researcher sees in Glowiński's prose a significant disproportion between the fragile memories' material and the extensive meta-narrative. It can actually be understood as a supercategory where analysing, inquiring and answering previously asked questions takes on the form of a narrative filter that distances, delays, and slows down the story itself. Memories are essentially devoid of tension and drama, they have no punch lines, they are burdened with self-interpretation, striving to name and explain the meaning of the phenomena described, having no power of interaction, they lose their visual appearance, color, specificity (Ubertowska, 2011, p. 860).

\section{Cited Works}

Głowiński, M. (2005). The Black Seasons. Evanston: Northwestern University Press. Grynberg, H. (2011). Holocaust jako nowe doświadczenie literackie. In: T. Majewski, A. Zeidler-Janiszewska, eds., Pamięć Shoah. Kulturowe reprezentacje i praktyki upamiętnienia. Łódź: Wydawnictwo Officyna, pp. 785-796. Krupa, B. (2013). Opowiedzieć Zagładę. Polska proza i historiografia wobec Holocaustu (1987-2003). Kraków: Universitas. Ubertowska, A. (2011). Shoah i literatura na „obrzeżach mowy“. O prozie Michała Głowińskiego i Marka Bieńczyka. In: T. Majewski, A. Zeidler-Janiszewska, eds., Pamięć Shoah. Kulturowe reprezentacje i praktyki upamiętnienia. Łódź: Wydawnictwo Officyna, pp. 855-864. 


\section{Further References}

Głowiński, M. (1998). Czarne sezony. Warszawa: Open. Kowalska-Leder, J. (2009). Doświadczenie Zagłady z perspektywy dziecka w polskiej literaturze dokumentu osobistego. Wrocław: Wydawnictwo Uniwersytetu Wrocławskiego. Grynberg H. (2002). Pokolenie Shoah. Odra, (4), p. 37-49. Kuczyńska-Koschany, K. (2008).,,Nosiłem w sobie strach i nie znałem języka, którym bym mógł mówić”. O Czarnych sezonach Michała Głowińskiego. Polonistyka, (9), pp. 36-41. Kurkiewicz, J. (2003). Punkty pamięci. Tygodnik Powszechny, 59(24), available at: www2.tygodnik.com.pl/ksiazki/24/ksiazki03.php [Accessed: 07.07.2019]. Leociak, J. (1998). Wyjście z piwnicy. Rzeczpospolita, (126), pp. 12-13. Łukasiewicz, J. (1998). Wielkie i mniejsze prozy Głowińskiego. Nowe Książki, (9), pp. 50-51. Łuszczykiewicz, P. (2006). Przeżyć i pisać. Nowe Książki, (6), p. 53. Radziwon, M. (2006). Ostra rozprawa z nieznośną pamięcią. Gazeta Wyborcza, 18(32), p. 16. Tec, N. (1982). Dry Tears: The Story of a Lost Childhood. Westport: Wildcat Publishing. Ubertowska A. (2007). Świadectwo - trauma - glos. Literackie reprezentacje Holokaustu. Kraków: Universitas. Ubertowska, A. (2011). „Kręgi obcości”, podwójne wyjście. Projekt autobiograficzny Michała Głowińskiego. Teksty Drugie, 22 (4), pp. 195-205.

$\mathrm{AF}$ 